УДК 903.21 (477.7) Ольвія

DOI: https://doi.org/10.33782/eminak2021.1(33).501

\title{
ЗНАРЯДДЯ РИБАЛЬСТВА, ЗНАЙДЕНІ У ПРИМІСЬКИХ САДИБАХ ОЛЬВІЇ
}

\author{
Валентина Папанова ${ }^{1}$, Світлана Ляшко 2 \\ ${ }^{1}$ Бердянський державний педагогічний університет (Бердянськ, Україна) \\ e-mail: vpapanova1953@gmail.com \\ ORCID: https://orcid.org/0000-0003-3633-3598 \\ ${ }^{2}$ Інститут біографічних досліджень \\ Національної бібліотеки України імені В.I. Вернадського (Київ, Україна) \\ e-mail: lyashko.svetlana@gmail.com \\ ORCID: https://orcid.org/0000-0003-2250-6718
}

Стаття присвячена аналізу та класифікації 41 рибальського грузила з приміських садиб Ольвї - Широка балка 6 другої третини V - початку III cm. до н.е. та Широка балка 7 кінця $V-30$-х років IV cm. до н.е.

На сьогодні відсутня статистика і комплексна типологічна класифікація цих артефактів для всіх періодів існування Ольвії та ї̈ сільськогосподарської округи. Це ускладнює їх вивчення, визначення функціонального призначення, створення відповідної типології, а також не сприяє удосконаленню класифікації знарядь риболовлі, вивченню процесів, методів, особливостей рибальства у конкретних регіонах. Окрім того, функціональне призначення деяких видів грузил досі залишається дискусійним.

Відповідь на запитання щодо практичного використання грузил з садиб треба шукати у міждисциплінарному просторі й аналізі взаємозв'язку конкретних рибальських знарядь із особливостями відповідної акваторії та видового складу риби.

Ключові слова: Ольвія, садиби, рибальство, грузила, класифікація, міждисциплінарний простір, каталог

Дослідники соціально-економічної історії античних держав Північного Причорномор'я, зокрема Ольвії та їі хори, однозначні у визначенні значущості рибного промислу в зоні Нижнього Побужжя та Нижнього Подніпров'я, важливої складової економіки та господарського життя Ольвійського полісу, продукти якого використовувалися для харчування населення та були предметом експорту1.

Географічне розташування полісу та його хори - море, річка, лиман (рис. 1, 1), видовий склад риби - впливали на характер риболовства (промисловий і для внутрішнього споживання), способи організації, технологію, визначення засобів і набір знарядь риболовлі тощо. У цьому контексті знаряддя риболовлі, як реальна змістовно-інформативна складова процесу потребують ретельного дослідження, класифікації й типології.

\footnotetext{
${ }^{1}$ Семенов-Зусер С.А. Рыбный рынок в Херсонесе // Вестник древней истории. 1947. № 2 (20). C. 239-240; Иевлев М.М. Роль ихтиофауны в жизни античного населения Нижнего Побужья // Borysthenika-2004. Материалы международной научной конференции к 100-летию исследований острова Березань Э.Р. фон Штерном. Николаев, 2004. С. 99; Одрін О. Природні ресурси та торгівельно-економічний потенціал античних держав Північного Причорномор'я: Нижнє Подністров'я та Нижнє Побужжя. Київ: Ін-т історії України НАНУ, 2020. С. 88; Журавльов О.П., Ієвлев М.М. Тваринництво, мисливство та природне середовище ольвійської держави архаїчних часів. Київ: Видавництво Олега Філюка, 2020. С. 66 та ін.
} 

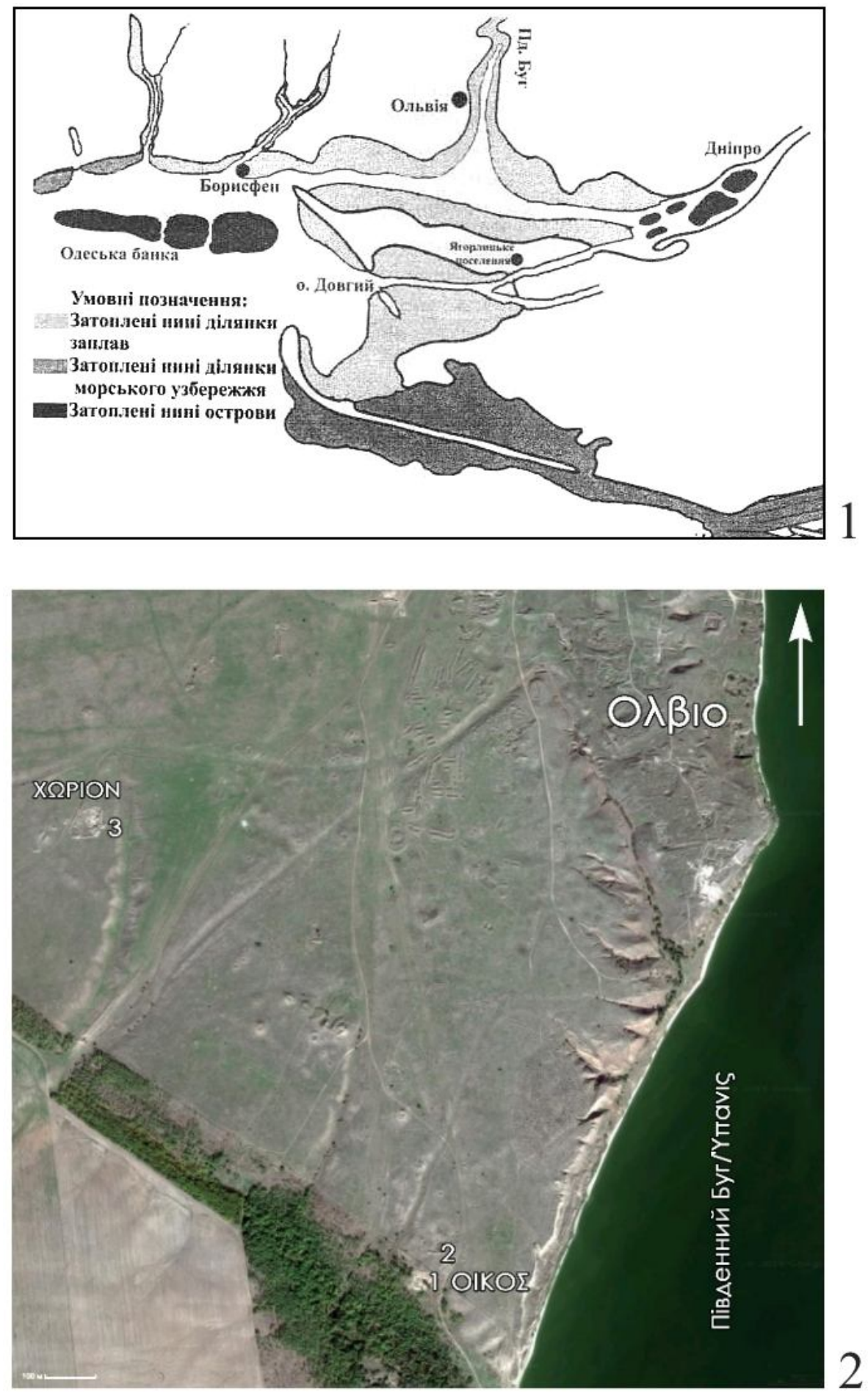

Рис.1. Нижнє Побужжя у середині I тис. до н.е.

(за О. Одрін 2005) -1; розташування садиб

Широка балка 6 і Широка балка 7 - 2

(за В. Папанова, С. Ляшко 2017) 
До знарядь рибальства відносять грузила/важки². Історіографія цієї категорії артефактів доволі численна: глиняні грузила пірамідальної форми, великі кам'яні грузила з отворами або з «перехватами», а також свинцеві, знайдені на античних поселеннях Північного Причорномор'я та Криму, досліджували В. Гайдукевич3 3 Н. Онайко4, Ю. Ляшенко ловних промислів та їх оснащення, зокрема про важки, цікавими $\epsilon$ праці В. Блаватського

Грузилам зі свинцю присвячені статті Д.Хмелевського ${ }^{10}$, Р. Рейди і С. Бейліної11. Проте переважають здебільшого публікації археологічного матеріалу12.

Водночас, майже по всім артефактам, віднесеним до групи «грузила», які знайдені в Ольвії та її хорі, відсутня статистика та повноцінні публікації знахідок, за винятком важків свинцевих. Зазначимо, що дещо краще вивчені ці артефакти 3 античних поселень Криму.

Така ситуація ускладнює їх вивчення, визначення функціонального призначення, створення відповідної типології, а також не сприяє вдосконаленню класифікації знарядь риболовлі, вивченню процесів, методів, особливостей рибальства у конкретних регіонах. Тому доцільним $\epsilon$, на наш погляд, зауваження О. Куликова, що «одна з найбільших груп грузил, яка об'єднує пірамідальні, конічні та дископодібні гончарні і ліпні вироби, залишається найменше вивченою»13.

Окрім того, функціональне призначення деяких видів важків досі залишається дискусійним в археологічному середовищі. Це стосується питання використання

\footnotetext{
2 Словник української мови. URL: https://sum20ua.com/Entry/index?wordid=6395\&page=233

3 Гайдукевич В.Ф. К вопросу о ткацком ремесле в боспорских поселениях // Боспорские города. Материалы и исследования по археологии СССР (25). Москва: Изд-во АН СССР, 1952. С. 395-414.

4 Онайко Н.А. О фанагорийских грузилах // Фанагория. Материалы и исследования по археологии СССР (57). Москва: Изд-во АН СССР, 1956. С. 154-160.

5 Ляшенко Н.Ф., Ляшенко Ю.Н. О первых рыболовах Восточного Крыма // Рыбное хозяйство Украины. 2005. № 1. С. 48-49; Ляшенко Н.Ф. О рыбаках и рыбном промысле в античную епоху // Рибне господарство України. 2007. № 3-4. С. 73-78.

${ }^{6}$ Молев Е.А. О рыболовстве в Китее // Боспорские исследования. Вып. XXV. Симферополь - Керчь: ТОВ «Керченська міська друкарня», 2011. С. 123-142.

7 Блаватский В.Д. Античная археология Северного Причерноморья. Москва: Издательство Академии наук СССР, 1961. С. 44.

8 Иевлев М.М. Роль ихтиофауны в жизни античного населения Нижнего Побужья// Borysthenika2004: материалы международной научной конференции к 100-летию исследований острова Березань Э.Р. фон Штерном. Николаев, 2004. С. 100.

9 Куликов А.В. Материалы к изучению древних морских промыслов // Древности Боспора. 1998. Т. 1. С. 186-201; Куликов А.В. Археологические свидетельства рыболовства на античном городище Акра // Боспорские исследования. Вып. 9. Симферополь - Керчь: ТОВ «Керченська міська друкарня», 2005. С. 251-270.

10 Хмелевский Д.Н. Свинцовые изделия участка «Т» Березанского античного поселения // Археологія і давня історія України. 2015. Вип. 1 (14). С. 227.

11 Рейда Р.Н., Бейлина С.А. Кольцевые свинцовые грузила из Карантинной бухты // Підводна техніка і технологія. Всеукраїнська науково-технічна конференція з міжнародною участю. URL: https://www.academia.edu/28388380/

12 Штительман Ф.П. Поселення біля Закисової Балки // Археологічні пам'ятки УРСР. 1958. Т. II. C. 138; Отрешко B.М. Позднеархаические поселения Березанского лимана // Открытия молодых археологов Украины. Ч. І. Киев: Наукова думка, 1976. С. 32; Крыжицкий С.Д., Буйский С.Б., Бураков А.В., Отрешко В.М. Сельская округа Ольвии. Киев: Наукова думка, 1989. С. 125, 136; Былкова В.П. Нижнее Поднепровье в античную эпоху (по материалам раскопок поселений). Херсон: Издво ХГУ, 2007. С. 73-74 та ін.

13 Куликов А.В. Материалы к изучению древних морских промыслов... С. 186.
} 
пірамідальних грузил для риболовлі, або в якості приладдя для ткацтва. У 50-х роках XX ст. В. Гайдукевич підтримав тезу західноєвропейських дослідників, зокрема М. Кімаковича-Вінницького і Л. Рея, про використання керамічних пірамідальних грузил тільки у вертикальних ткацьких верстатах ${ }^{14} .3$ його висновками не погодилася Н. Онайко, яка вважала, що частина таких важків, добре обпалених та обкатаних у воді, використовувалася в якості рибальських грузил, а не обкатані - у ткацьких верстатах ${ }^{15}$. В останні десятиріччя твердження В. Гайдукевича підтримали О. Куліков 16 та О. Бутягін ${ }^{17}$. Проте $€$ інший погляд $€$. Молєва. На його думку, великі конічні, пірамідальні та дископодібні керамічні грузила застосовувалися саме у рибальстві. Окрім того, він підтримав точку зору Н. Онайко18, що частина важків були багатофункціональними ${ }^{19}$.

Об’єктом дослідження обрані знаряддя риболовлі - 41 грузило, знайдене на садибах одноосібного користування Широка балка 6 (ойкос) другої третини V - початку III ст. до н.е. і Широка балка 7 (хоріон) кінця V - 30-х років IV ст. до н.е. Садиби знаходилися на південній околиці ольвійського городища $20:$ перша (ойкос) - на відстані 0,8 км від Ольвії та 0,3-0,4 км від сучасного узбережжя Дніпро-Бузького лиману, а друга (хоріон) - у 1,5 км від городища та 1,2-1,4 км від лиману (рис. 1,2).

Переважна більшість артефактів, пов'язаних з рибальством, знайдено на садибі Широка балка 7. Окрім грузил, знаряддя рибальства представлені залізним гачком, який розкопали на цій самій садибі 21.

3 іхтіологічних матеріалів на обох садибах виявлені кістки осетрових і коропових порід риб, а також судака, сому та стулки мідій 22 . Вони аналогічні решткам видів риб, які знайшли при розкопках Ольвії та її хори ${ }^{23}$.

Зазначимо, що на хоріоні in situ дослідили стулки молюсків і скупчення рибної луски поряд з піччю на подвір'ї приміщення № 924, а у напівземлянці II поблизу вогнища лежали кістки риби, стулки мідій, три грузила й обкатані маленькі камінці 25 . Відзначимо, що у раціоні харчування ольвійського населення молюски займали не останнє місце ${ }^{26}$.

\footnotetext{
14 Гайдукевич В.Ф. К вопросу о ткацком ремесле в боспорских поселениях... С. 397.

15 Онайко Н.А. О фанагорийских грузилах // Фанагория. Материалы и исследования по археологии СССР (57). Москва: Изд-во АН СССР,1956. С. 155.

16 Куликов А.В. Материалы к изучению древних морских промыслов... С. 190.

17 Бутягин А.М. Производство и использование пирамидальных керамических грузил на античном Боспоре // Боспорские чтения XI. Керчь, 2010. С. 51.

18 Онайко Н.А. О фанагорийских грузилах... С. 155.

19 Молев Е.А. О рыболовстве в Китее... С. 124

20 Папанова В.А., Ляшко С.Н. Пригородные усадьбы ольвийской хоры V-IV вв. до н.э. Stratum plus. 2015. № 3. C. 227, 236.

21 Папанова В.А., Ляшко С.М. Вироби із заліза класичного часу з приміських садиб Ольвії // Археологія. 2018. № 2. С. 75, 77.

22 Див. звіти Маркова О.В. за 2003-2012 рр. у Науковому архіві Інституту археології НАН України.

${ }^{23}$ Крижицький С.Д. Про вплив змін оточуючого середовища на історичний розвиток Ольвійскої держави // Археологія. 1995. № 2. С. 15; Журавльов О.П., Ієвлев М.М. Тваринництво, мисливство та природне середовище ольвійської держави архаїчних часів... С. 69-70.

24 Ляшко С., Папанова В. Про деякі знаряддя рибальства, знайдені у садибі Широка Балка 7 ближньої хори Ольвії // FORUM OLBICUM III: до 70-річчя з дня народження В.В. Крапівіної. Матеріали міжнародної археологічної конференції 4-6 травня 2020 р. Миколаїв: Науково-дослідний центр «Лукомор'є», 2020. С. 83.

25 Папанова В.А., Ляшко С.Н. Отчет. Охранные раскопки в юго-западной части некрополя Ольвии («Усадьба», участок «Западный») // Науковий архів Інституту археології НАН України. 2007/1г.

26 Журавльов О.П., Ієвлев М.М. Тваринництво, мисливство та природне середовище ольвійської держави архаїчних часів... С. 70.
} 

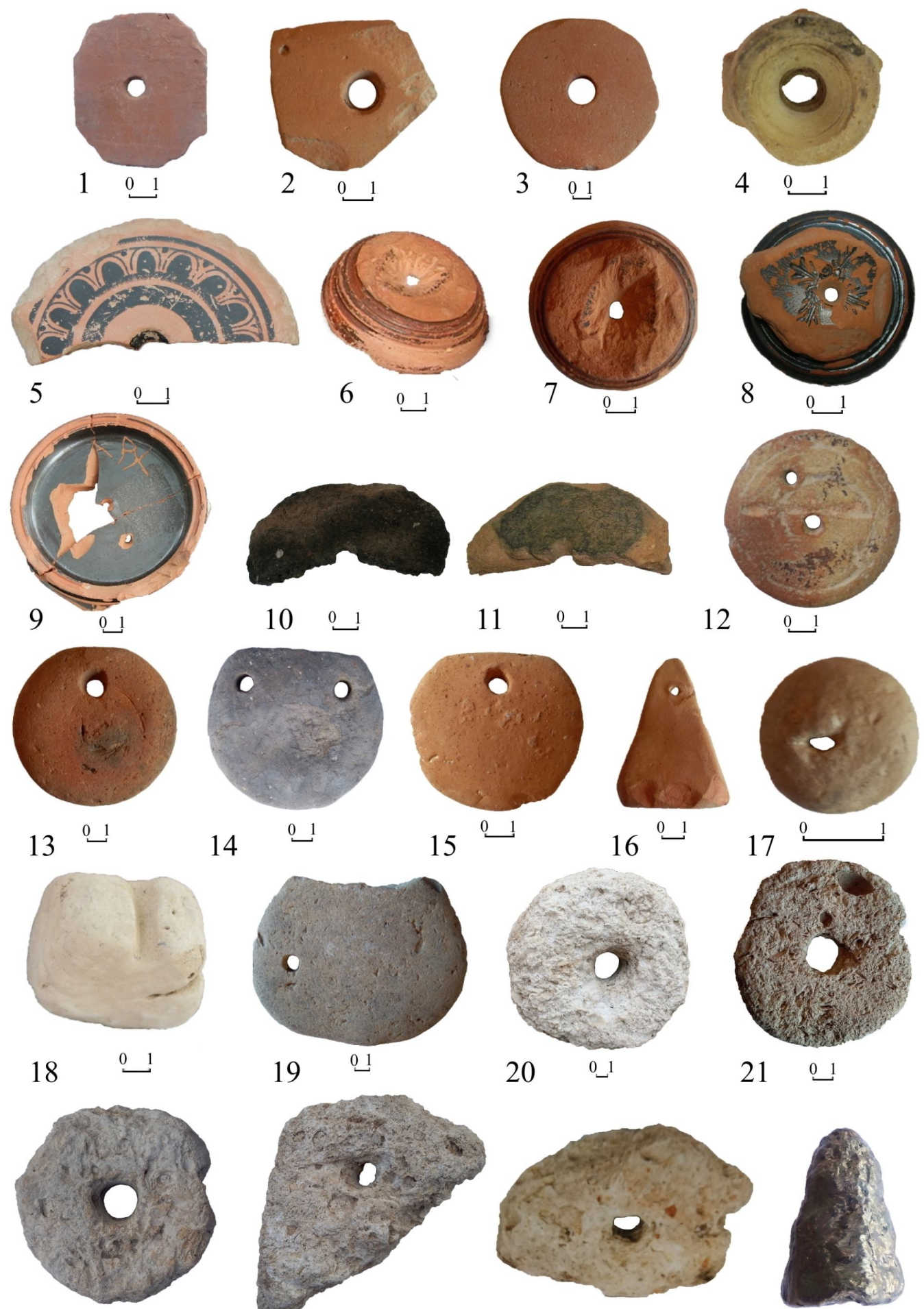

22
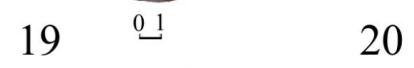

$21 \stackrel{0}{-1}$
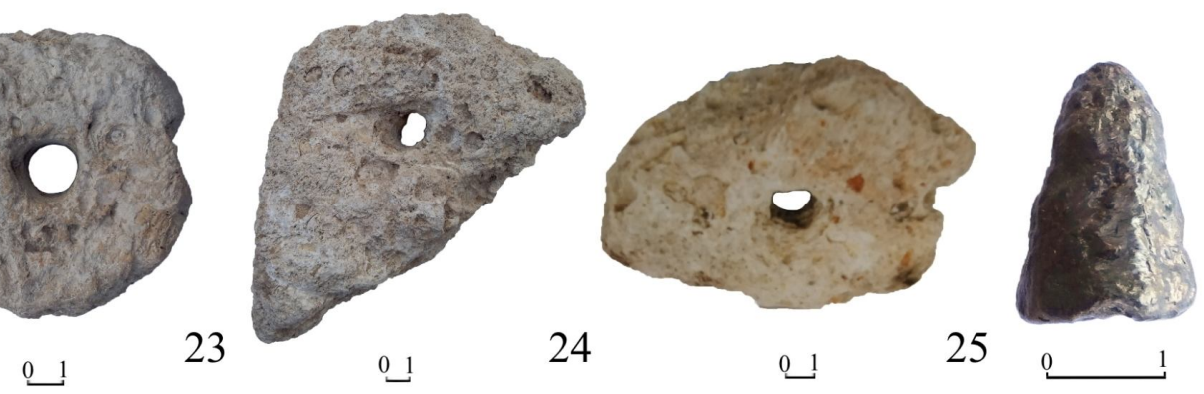

Рис.2. Грузила риболовецькі з садиби Широка балка 7 (за С.Ляшко, В.Папанова 2020) 
У житлових і господарських приміщеннях садиби Широка балка 7, а також у перевідкладеному грунті знайдено 36 грузил (26 керамічних, 1 ліпне, 7 кам'яних, 1 свинцеве). Зокрема, 10 грузил розкопані на площі першого, 5 - другого господарчих комплексів; 2 - у напівземлянці I, 3 - у напівземлянці II, 2 - у напівземлянці III. Окрім того, по одному грузилу знайдено у різних частинах садиби (разом 13 екз.).

На садибі Широка балка 6, незважаючи на її близькість до узбережжя лиману, розкопано тільки п’ять риболовецьких грузил (1 керамічне, 1 ліпне, не обпалене, 2 кам'яних, 1 свинцеве).

Відносно класифікації цих виробів. Традиційно їх поділяють на кам’яні, керамічні та свинцеві грузила, виокремлюючи групу важків пірамідальних, конічних і дископодібних гончарних і ліпних. Цікаву версію класифікації запропонував 0 . Куліков ${ }^{27}$, який взяв за основу класифікацію сучасних риболовецьких знарядь і способів лову А. Трєщєва ${ }^{28}$, що базується на принципах лову риби. Є. Молєв також посилається на класифікацію А. Трєщєва та додатково відносить до групи керамічних грузил округлі важки, розкопані у Китеї 29.

Проте, на жаль, на сьогодні відсутня комплексна типологічна класифікація цих артефактів для всіх періодів існування Ольвії та її сільськогосподарської округи.

Важки, знайдені на ойкосі та хоріоні, відрізняються один від одного матеріалом і засобами виготовлення. Додатковим показником грузил є їх форма. Суттєвою ознакою для визначення функціонального призначення виступає вага. За означеними критеріями вони були поділені на чотири умовних групи.

I група - грузила керамічні, виготовлені з підсобного матеріалу (уламків посуду): зі стінок амфор і піфосів, з кришок посудин (каструля, червонофігурна лекана), з днищ червоноглиняних глеків з покриттям і кухонного посуду, піддонів чорнолакових киликів і чаші (рис. $2,1-11 ; 3,1)$.

Про те, що фрагменти посуду (стінки, кришки, ручки, днища, піддони) дійсно використовувалися як важки, свідчить той факт, що вони були обкатані водою та майже всі мали отвори. Однак не мали отворів грузила зроблені зі стінок піфосу (рис. 3,8$)$ та амфор, знайдені на обох садибах (більше на ойкосі). Вірогідно, що такі важки перев'язували навхрест і кріпили знизу до сіток30.

Цікаво, що в якості грузил, використали чорнолакові фрагменти піддона кіліка з графіті NIKH V ст. до н.е. та днище чаші з графіті APX останньої чверті IV ст. до н.е. (рис. 2, 9)31. Зазначимо, що на дні цієї чорнолакової чаші зробили два отвори, зміщені до одного краю, аналогічні до отворів на округлих керамічних важках. Вірогідно, що такі грузила використовували тільки один-два рази.

II група - грузила керамічні, спеціально вироблені у відповідних формах: круглі, пласкі з отворами; дископодібні з отворами; прямокутні пірамідальні з отворами; у вигляді кульки з отвором; ліпні (рис. 2, 12-16; 3, 6-7).

\footnotetext{
27 Куликов А.В. Материалы к изучению древних морских промыслов... С. 186.

28 Трещев А.И. Научные основы селективного рыболовства. Москва: Пищевая промышленность, 1974. $446 \mathrm{c}$.

29 Молев Е.А. О рыболовстве в Китее... С. 124.

30 Донедавна азовські рибалки так кріпили каміння, яке заміняло грузила, до рибальських сіток.

31 Папанова В.А, Диатроптов П.Д. Граффити с пригородных усадеб Ольвии // Північне Причорномор'я за античної доби. Київ: Інститут археології НАНУ, 2017. С. 83-84, рис. 1, 2; 86-87, рис. 2, 6.
} 
Серед цієї групи вирізняється кругле грузило з двома отворами та графіті у вигляді тунця 32 (рис. 3,$12 ; 3,9-10$ ). Зазначимо, що грузила з графіті розкопані у Китеї, Пантикапеї, Тіритаці, Фанагорії, Херсонесі33 та на інших поселеннях Північного Причорномор'я та Криму.

Цікавою $є$ технологія вироблення круглих, пласких і дископодібних з отворами грузил. Спочатку їх змоделювали у круглих формах, а перед випалом вирівняли над отворами.

Інтерес викликають два ліпних грузила. Одне з них, розкопане на ойкосі, - заготівка для випалу (рис. 2, 2).

III група - грузила кам'яні: дископодібні з отворами; кільцеподібної форми; неправильної чотирикутної форми (рис. 2, 19-24; 3, 3-4).

Грузила перших трьох груп, скоріше за все, використовували для відціджуючих знарядь для вилову риби (невід, сітки-накидки) ${ }^{34}$.

IV група - грузила свинцеві: конусоподібне, колоподібне й овальне з отворами (рис. 2,$5 ; 3,25)$.

В античні часи у Північному Причорномор'ї колоподібні й овальні важки різних розмірів використовувалися для накидних сіток 35 .

Ймовірно, що конусоподібне грузило призначалося для вудки, як і керамічне у формі кульки. На думку О. Кулікова, ловля риби на вудку не мала великого значення, а була розвагою36. Його погляд підтримав і $€$. Молєв 37 . Зазначимо, що це не зовсім відповідає дійсності, оскільки основна маса населення ольвійського поліса - це середньо- або малозаможні верстви ${ }^{38}$, яка навряд чи мала час на таку розвагу. Про те, що для бідного населення рибалка на вудку була не розвагою, а буденним заняттям, свідчать античні автори. Зокрема, в ідилії «Рибалки» Феокріта/Теокріта ${ }^{39}$ бідний рибалка Асфілон розповідає приятелю Оспілону свій сон про те, як він спіймав на вудку золоту рибину. У відповідь він почув: «справжню ловити заходьмося рибу, / Щоб не загинути з голоду нам».

Отже, одним із напрямів господарської діяльності жителів садиби Широка балка 7 було рибальство та переробка риби (копчення, в'ялення, просушка), що здійснювалося у господарському приміщенні № $2^{40}$ та господарському приміщенні 1 напівземлянки I41. Залишки продукції риболовлі могли продаватися на внутрішньому ринку Ольвії.

\footnotetext{
32 Ляшко С., Папанова В. Про деякі знаряддя рибальства... С. 83, рис. 1, 12.

33 Гайдукевич В.Ф. К вопросу о ткацком ремесле в боспорских поселениях... С. 400; Онайко Н.А. 0 фанагорийских грузилах... С. 158-159, рис. 2-3; Соломоник Э.И. Херсонесские глиняные грузила с надписями // Северо-Западный Крым в античную эпоху. Киев: 1994. С. 144; Молев Е.А. О рыболовстве в Китее... С. 124, 135, 47.

34 Куликов А.В. Материалы к изучению древних морских промыслов... С. 186.

35 Куликов А.В.Археологические свидетельства рыболовства на античном городище Акра... С. 255-256; Рейда Р.Н., Бейлина С.А. Кольцевые свинцовые грузила из Карантинной бухты...

${ }^{36}$ Куликов А.В. Материалы к изучению древних морских промыслов... С. 190.

37 Молев Е.А. О рыболовстве в Китее... С. 125.

38 Крыжицкий С.Д., Русяева А.С., Крапивина В.В., Лейпунская Н.А., Скржинская М.В., Анохин В.А. Ольвия античное государство в Северном Причерноморье. Киев: Институт археологии НАН Украины, 1999. С. 404, 415.

39 Феокріт // О.І. Білецький (упорядник). Антична література. Київ: Радянська школа, 1968. С. $337-$ 349.

40 Папанова В.А., Ляшко С.Н. Пригородные усадьбы ольвийской хоры V-IV вв. до н.э.... С. 242.

41 Ibid. C. 237.
} 

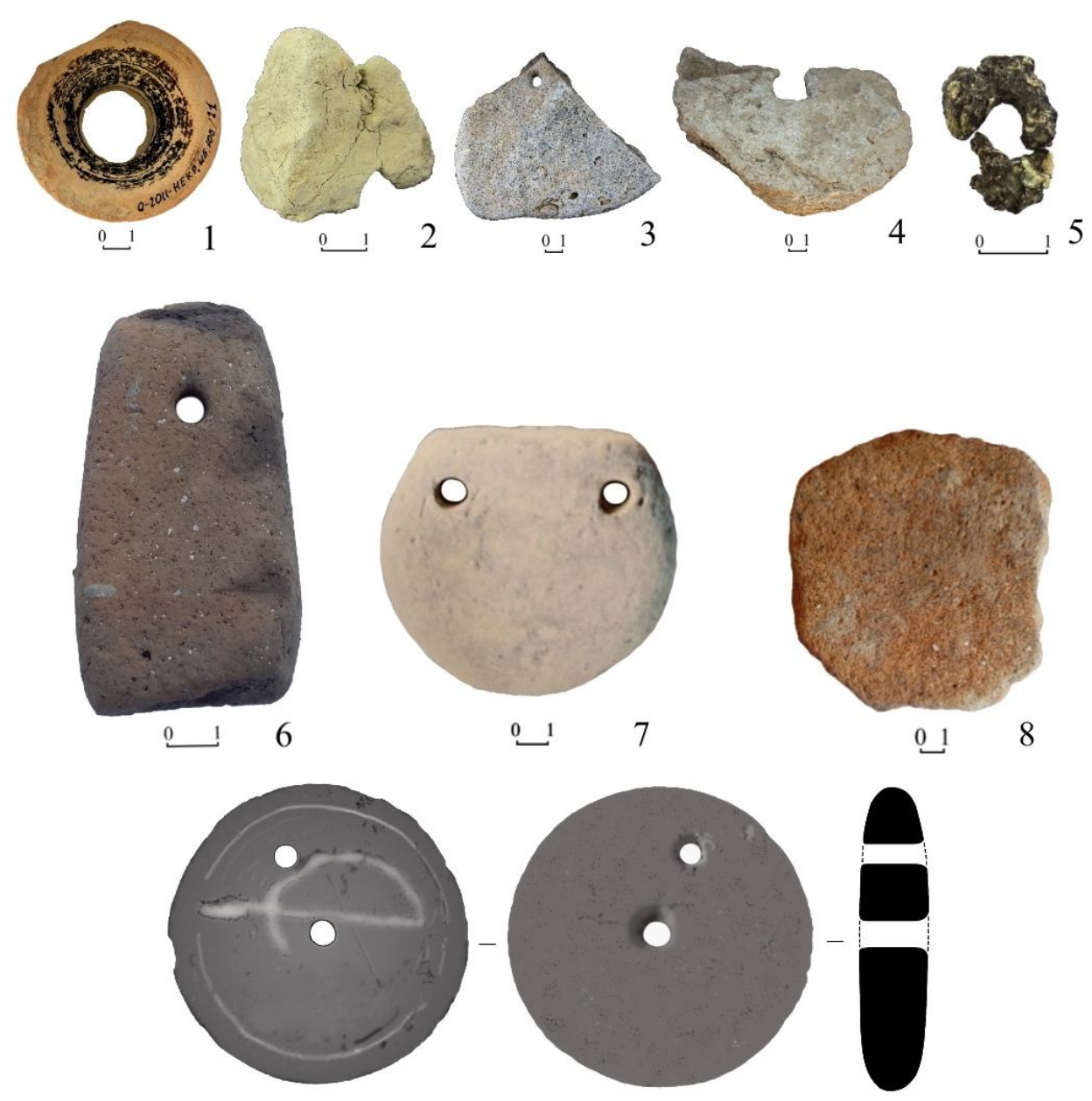

0

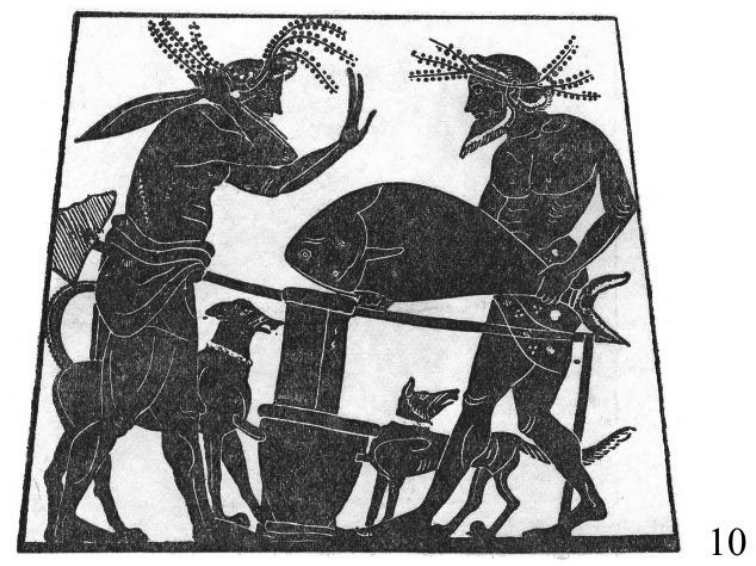

Рис.3. Грузила з садиби Широка балка 6 (1-5) та широка балка 7 (6-7); грузило з графіті (9);

10 - оброблення тунця, чорнофігурна ойнохоя із Рульги у Берлінському музеї (за С.А. Семенов-Зусер 1947) 
Відповідь на запитання щодо остаточного визначення практичного використання збірки грузил з садиб треба шукати у міждисциплінарному просторі й аналізі взаємозв'язку конкретних рибальських знарядь з особливостями відповідної акваторії та видового складу риби, який складався протягом тисячоліть. Зокрема, пірамідальні керамічні та свинцеві конусоподібні грузила могли бути багатофункціональними.

Остаточні висновки можливі при міждисциплінарному підході - поєднання археології, географії (морфологічні особливості регіону), етнографії (порівняльно-етнографічні дослідження технології рибальства), відомості з іхтіофауни (видовий склад риб), використання методів природничих наук (датування пам'яток, аналіз матеріалів). Це дозволить посилити розуміння особливостей риболовлі та її господарської значущості у зоні Нижнього Побужжя та Нижнього Подніпров'я у часи давньої Ольвії.

\section{$* * *$ \\ КАТАЛОГ \\ I група - грузила з фрагментів посуду}

\section{Зі стінок амфор та піфосу}

1. Грузило з стінки амфори, з закругленими кутами - 0-2003, Некр. ЮЗ (ус)/50. Обкатане (рис. 2, 1).

Розміри: довжина 4,5 см, ширина 4,2 см, товщина 0,5 см, діаметр отвору 0,7 см. Вага 28 грамів.

Грузило знайдене на садибі Широка балка 7 у приміщенні 2 першого господарського комплексу, який датується кінцем V-IV ст. до н.е. ${ }^{42}$

2. Грузило стінки амфори, неправильної форми - 0-2005, Некр. (Ю-3)/52. Обкатане (рис. 2, 2).

Розміри: 4,8×4,3 см, товщина 0,5 см, діаметр отвору зверху 0,7 см, діаметр отвору знизу 0,9 см. Вага 26 грамів.

Грузило знайдене на садибі Широка балка 7 поблизу від вівтаря (кв. 34). Датується IV ст. до н.е.

3. Грузило з стінки амфори, у формі кола з отвором по середині - O-2005, Некр. (Ю-3) № 47. Обкатане (рис. 2, 3).

Розміри: 7,85×8,1 см, товщина 1 см, діаметр отвору 1,5 см. Вага 88 грамів.

Грузило знайдене на садибі Широка балка 7 поблизу від вівтаря. Датується IV ст. до H.e.

4. Грузило з стінки піфосу, закруглене - O-2006, Некр. Ю3 (ус)/51. Обкатане (рис. 3, 8).

Розміри: довжина 9,6 см, ширина 8,9 см, товщина 1,9 см. Вага 289 грамів.

Грузило знайдене на садибі Широка балка 7 в приміщенні 2 напівземлянки I, яка датується рубежем V-IV - першою третиною IV ст. до н.е.

\section{3 кришок від посудин}

5. Грузило з ручки від каструлі з отвором - 0-2003, Некр. ЮЗ (ус)/19. Обкатане (рис. 2, 4).

\footnotetext{
42 Папанова В.А., Ляшко С.М. Господарські споруди в системі приміських садиб Ольвії Понтійської (підсумки розкопок 2003-2013 pp.) // The Crimea and the Northern Black Sea Coast in Archaeological Research 1956-2013. Swiatowit Supplement Series C: Pontika et Caucasica. Warsaw: Institute of Archaeology of the University of Warsaw, 2017. Vol. I. P. 252.
} 
Розміри: діаметр 3,1 см, діаметр отвору зверху 1 см, діаметр отвору знизу 0,6 см. Вага 22 грами.

Знайдене на садибі Широка балка 7 в приміщенні 1 першого господарського комплексу, який датується кінцем V-IV ст. до н.е.

6. Грузило з кришки від лекани, з отвором посередині, оброблене, половина - O-2003, Некр. ЮЗ (ус)/53. Обкатане (рис. 2, 5).

Розміри: діаметр 8,6 см, товщина 0,9 см, діаметр отвору 1,1 см. Вага 50 грамів.

Знайдене на садибі Широка балка 7 на території першого господарського комплексу, який датується кінцем V-IV ст. до н.е.

\section{3 піддонів чорнолакових киликів та чаші}

7. Грузило зроблене з ніжки чорнолакового килика V ст. до н.е. $з$ графіті NIKH, 3 отвором, половина - 0-2009, Некр. ЮЗ/23. Обкатане.

Розміри: діаметр 4,6 см, діаметр отвору 0,5-1 см. Вага 16 грамів.

Знайдене на садибі Широка балка 7, підйомний матеріал.

8. Грузило, зроблене з ніжки чорнолакового килика V ст. до н.е., з отвором - O-2011, Некр. ЮВ.ШБ/21. Обкатане (рис. 3,1 ).

Розміри: діаметр 8 см, діаметр отвору 3 см. Вага 28 грамів.

Знайдене на садибі Широка балка 6 (кв. 15 - господарська яма № 7), культурний шар насичений матеріалом V-IV ст. до н.е.

9. Грузило з піддону чорнолакового килика з отвором посередині, оброблене - O2007, Некр. ЮЗ (ус)/69. Обкатане (рис. 2, 6).

Розміри: діаметр піддону 5 см, висота 1,8 см, діаметр отвору зверху 0,5 см, діаметр отвору знизу 0,4 см. Вага 27 грамів.

Знайдене на садибі Широка балка 7 у приміщенні 11 житлового будинку, який датується другою третиною - 30-ми роками IV ст. до н.е.

10. Грузило з піддону чорнолакового килика з отвором посередині, оброблене - O2007, Некр. Ю3 (ус)/100. Обкатане (рис. 2, 7).

Розміри: діаметр піддону 5,2 см, висота 1,9 см, діаметр отвору 0,5 см. Вага 45 грамів.

Знайдене на садибі Широка балка 7 у північній частині приміщення 13 житлового будинку, який датується другою третиною - 30-ми роками IV ст. до н.е.

11. Грузило з піддону чорнолакового килика з отвором посередині, оброблене - O2007, Некр. ЮЗ (ус)/112. Обкатане (рис. 2, 8).

Розміри: діаметр піддону 4,3 см, висота 1,6 см, діаметр отвору зверху 0,6 см, отвору знизу 0,4 см. Вага 26 грамів.

Знайдене на садибі Широка балка 7 у приміщенні 11 житлового будинку, який датується другою третиною - 30-ми роками IV ст. до н.е.

12. Грузило з дна чорнолакової чаші з графіті АРХ з двома отворами посередині, оброблене - O-2007, Некр. ЮЗ (ус)/9). Обкатане (рис. 3, 9).

Розміри: діаметр 8,35 см, висота 1,9 см, діаметр отвору по центру 0,3 см, діаметр другого отвору знизу 0,3 см. Вага 98 грамів.

Знайдене на садибі Широка балка 7 у приміщенні 11 житлового будинку, який датується другою третиною - 30-ми роками IV ст. до н.е.

\section{3 стінок та днищ глеків}

13. Грузило з стінки сіроглиняного глека з отвором по центру - 0-2006, Некр. ЮЗ (ус)/24. Обкатане.

Розміри: 4×7,2 см, товщина 0,5 см, діаметр отвору 0,3-0,5 см. Вага 37 грамів.

Грузило знайдене на садибі Широка балка 7 (кв. 30), культурний шар насичений матеріалом IV ст. до н.е.

14. Грузило зі стінки червоглиняного глека з отвором у верхній частині - 0-2006, Некр. ЮЗ (ус)/59. Обкатане. 
Розміри: 5×8,8 см, товщина 0,4 см, діаметр отвору 0,5 см. Вага 27 грамів.

Знайдене на садибі Широка балка 7 у підлозі землянки II, датується IV ст. до н.е.

15. Грузило з дна червоноглиняного з чорним покриттям глека з отвором посередині, половина - 0-2006, Некр. Ю3 (ус)/25. Обкатане (рис. 2, 11).

Розміри: діаметр 7,6 см, товщина 1,1 см, діаметр отвору 0,7 см. Вага 72 грама.

Знайдене на садибі Широка балка 7 (кв. 36). Датується IV ст. до н.е.

16. Грузило з дна червоноглиняного з чорним покриттям глека з отвором посередині, половина - 0-2009, Некр. ЮЗ /290. Обкатане.

Розміри: довжина 4,1 см, товщина 1 см, діаметр отвору. Вага 21 грам.

Знайдене на садибі Широка балка 7 у приміщенні 2 другого господарського комплексу, який датується другою третиною - 30-ми роками IV ст. до н.е.

\section{3 днищ кухонного посуду}

17. Грузило з дна каструлі з отвором посередині, половина - 0-2009, Некр. Ю3/274. Обкатане (рис. 2, 10).

Розміри: довжина 6,85 см, ширина 3,5 см, товщина 0,6 см, діаметр отвору 0,7 см. Вага 26 грам.

Знайдене на садибі Широка балка 7 у полу землянці III, датується IV ст. до н.е.

\section{Круглі, виготовлені у формах}

\section{II група - грузила керамічні}

18. Грузило з двома отворами, з графіті у вигляді тунця - O-2013, Некр. ШБ. ЮВ/Б/н. Обкатане (рис. 2, 12; 3, 9).

Розміри: діаметр 6,1 см, товщина 1,2 см, діаметр отвору над графіті 0,7-0,9 см, діаметр отвору під графіті 0,5 см. Вага 60 грамів.

Знайдене на березі лиману поблизу садиби Широка балка 6, яка датується другою третиною V - початком III ст. до н.е.

Найближчі аналогії - графіті вигляді у схематичного зображення камбали/калкана 3 Фанагорії ${ }^{43}$ та хребта цієї ж риби з Китею ${ }^{44}$.

19. Грузило майже кругле, з опуклими сторонами і отвором, зміщеним до краю - $O$ 2007, Некр. ЮЗ (ус)/102. Обкатане (рис. 3, 13).

Розміри: діаметр 7,6 см, товщина 1,5 см, діаметр отвору 1-1,5 см. Вага 127 грамів.

Знайдене на садибі Широка балка 7 у напівземлянці II, датується IV ст. до н.е.

Аналогічне важку з Фанагорії45.

20. Грузило пласке з двома отворами, зміщеними до одного краю. Над отворами вирівняне - 0-2003, Некр. ЮЗ (ус)/14. Обкатане (рис. 2, 14).

Розміри: 7×7,5 см, товщина 1,2 см, діаметри отворів 1 см. Вага 134 грама.

Знайдене на садибі Широка балка 7 на території першого господарського комплексу, який датується кінцем V-IV ст. до н.е.

Аналогія - подібне грузилу з Китею46.

21. Грузило майже кругле, з опуклими сторонами і отвором, зміщеним до краю - $O$ 2007, Некр. ЮЗ (ус)/50. Обкатане (рис. 2, 15).

Розміри: діаметр 7,6 см, товщина 1,5 см, діаметр отвору 1-1,5 см. Вага 127 грамів.

Знайдене на садибі Широка балка 7 у кв. 47, на ньому відкриті напівземлянки II та III, які датуються IV ст. до н.е.

\footnotetext{
43 Онайко Н.А. О фанагорийских грузилах... С. 159, рис. 3 , 3.

44 Молев Е.А. 0 рыболовстве в Китее... С. 124, 135, 47.

45 Онайко Н.А. О фанагорийских грузилах... С. 158, рис. 2, 4; Куликов А.В. Материалы к изучению древних морских промыслов... С. 193, рис. 3.

46 Молев Е.А. 0 рыболовстве в Китее... С. 134, 35.
} 
Аналогічне № 19 та важку з Фанагорії ${ }^{47}$.

22. Грузило пласке з двома отворами, зміщеними до верху. Над отворами край вирівняний - 0-2003, Некр. ЮЗ (ус)/46). Обкатане (рис. 3, 7).

Розміри: 5,4×5,8 см, товщина 1,6 см, діаметри отвору лівого 2,8 см, правого 2,1 см. Вага 62 грама.

Знайдене на садибі Широка балка 7 на території першого господарського комплексу, який датується кінцем V-IV ст. до н.е.

Аналогія - грузило № 21 та з Китею48.

\section{Прямокутні та пірамідальні}

23. Грузило прямокутне з отвором у верхній частині - 0-2003, Некр. ЮЗ (ус)/14. Обкатане (рис. 3,6$)$.

Розміри: основа 2,3×3,1 см, висота 6,6 см, довжина граней 5,7-6,2 см, діаметр отвору 0,7 см. Вага 111 грамів.

Знайдене на садибі Широка балка 7 на території першого господарського комплексу, який датується кінцем V-IV ст. до н.е.

Аналогія - грузилам з Фанагорії ${ }^{49}$ та Китею50.

24. Грузило пірамідальне з отвором у верхній частині, половина - 0-2007, Некр. ЮЗ (ус)/34. Обкатане (рис. 2, 16).

Розміри: основа 4×5,7 см, довжина граней 5,8 см, діаметр отвору 0,3 см. Вага 62 грама.

Знайдене на садибі Широка балка 7 у приміщенні 2 другого господарського комплексу, який датується другою третиною - 30-ми роками IV ст. до н.е.

Аналогія - грузилам з Фанагорії ${ }^{51}$ та Китею52.

25. Грузило у формі кульки з отвором, зміщеним від центру - 0-2006, Некр. ЮЗ (ус)/71. Обкатане (рис. 2, 17).

Розміри: діаметр 1,7 см, діаметр отвору 0,2-0,3 см. Вага 6 грамів.

Знайдене на садибі Широка балка 7 у напівземлянці II, яка датується IV ст. до н.е.

\section{Ліпні}

26. Грузило прямокутної форми з округлими гранями, з перехопленням ближчим до одного краю та проріззю на одному з вужчих боків - 0-2009, Некр. Ю3/319. Обкатане (рис. 2, 18)

Розміри: $3,4 \times 3,8 \times 4,4$ см. Вага 88 грамів.

Знайдене на садибі Широка балка 7 у підлозі землянки III, яка датується IV ст. до н.е.

27. Грузило підпрямокутної форми з округлими гранями, з перехопленням ближчим до одного краю, не обпалене (заготовка) - 0-2011, Некр. ЮВ.ШБ/Б/н (рис. 3, 2).

Розміри: $1,2 \times 3,5 \times 4,7$ см. Вага 72 грама.

Знайдене на садибі Широка балка 6 , яка датується другою третиною V - початком III ст. до н.е.

Аналогія - грузило з Китею53.

\section{Дископодібні}

\section{III група - грузила кам'яні}

28. Грузило дископодібне з просвердленим отвором, половина - 0-2011, Некр.

\footnotetext{
47 Онайко Н.А. О фанагорийских грузилах... С. 158, рис. 2, 4.

48 Молев Е.А. О рыболовстве в Китее... С. 134, 35.

49 Онайко Н.А. О фанагорийских грузилах... С. 157, рис.1,9; С. 158, рис. 2, 13.

50 Молев Е.А. О рыболовстве в Китее... С. 131, 7; 133, 33;135, 41.

51 Онайко Н.А. О фанагорийских грузилах... С. 157, рис. 1, 10.

52 Молев Е.А. О рыболовстве в Китее... С. 131, 8.

53 Молев Е.А. О рыболовстве в Китее... С. 129, № 19.
} 
ЮВ.ШБ/70. Ракушняк (рис. 3, 3).

Розміри: 2,5×7×8,2 см. Вага 310 грамів.

Знайдене на садибі Широка балка 6 у приміщенні 1 житлового будинку, який датується другою третиною - 30-ми роками IV ст. до н.е.

29. Грузило дископодібне з просвердленим отвором, оббите з одного боку - O-2006, Некр. ЮЗ (ус)/48. Ракушняк (рис. 2, 19).

Розміри: 2,8×10,7×14,2 см. Вага 724 грама.

Знайдене на садибі Широка балка 7 у напівземлянці II, яка датується IV ст. до н.е.

\section{Кільцеподібні}

30. Грузило кільцеподібне з просвердленим посередині отвором, половина - O-2012, Некр. ЮВ.ШБ/143. Щільний вапняк (рис. 3, 4).

Розміри: 2,5×7×8,2 см. Вага 310 грамів.

Знайдене на садибі Широка балка 6 у господарчій ямі № 25, яка датується другою третиною - кінцем V ст. до н.е.

31. Грузило кільцеподібне з просвердленим посередині отвором - 0-2009, Некр. Ю3/291. Вапняк (рис. 2, 20).

Розміри: 4,7×12,3×12,7 см, діаметр отвору 2,7-3 см (низ/верх). Вага 780 грамів.

Знайдене на садибі Широка балка 7 у приміщенні 2 другого господарського комплексу, який датується другою третиною - 30-ми роками IV ст. до н.е.

32. Грузило кільцеподібне з просвердленим посередині отвором - 0-2009, Некр. ЮЗ/399. Щільний вапняк (рис. 2, 21).

Розміри: 2,7×7,6×8 см, діаметр отвору 1,5-2 см (низ/верх). Вага 169 грамів.

Знайдене на садибі Широка балка 7 на схід від приміщення 13 житлового будинку, який датується другою третиною - 30-ми роками IV ст. до н.е.

33. Грузило кільцеподібне з просвердленим посередині отвором - O-2003, Некр. ЮЗ (ус)/100. Щільний вапняк (рис. 2, 22).

Розміри: 2,7×7,6×8 см, діаметр отвору 1,5-2 см (низ/верх). Вага 169 грамів.

Знайдене на садибі Широка балка 7 на території першого господарського комплексу, який датується кінцем V-IV ст. до н.е.

34. Грузило кільцеподібне з просвердленим посередині отвором, половина - O-2008, Некр. ЮЗ /57. Щільний вапняк.

Розміри: діаметр 7 см, товщина 2 см, діаметр отвору 1,8 см. Вага 91 грам.

Знайдене на садибі Широка балка 7 на схід від приміщення 13 житлового будинку, який датується другою третиною - 30-ми роками IV cт. до н.е.

35. Грузило кільцеподібне з просвердленим посередині отвором, половина - O-2003, Некр. ЮЗ (ус)/143. Щільний вапняк.

Розміри: 0,9-1,2×1,9×7,5 см, діаметр отвору 0,9 см. Вага 134 грама.

Грузило знайдене на садибі Широка балка 7 на території першого господарського комплексу, який датується кінцем V-IV ст. до н.е.

Аналогія грузилам №30-35 - грузило з Китею54.

\section{Геометричних форм}

36. Грузило трапецієподібної форми з просвердленим отвором - O-2004, Некр. ЮЗ (ус)/77. Щільний вапняк (рис. 2, 23).

Розміри: 4,1×8,3×13,2 см, діаметр отвору 1,9 см. Вага 169 грамів.

Знайдене на садибі Широка балка 7 у приміщенні 1 (господарське) напівземлянки I, яка датується рубежем V-IV - першою третиною IV ст. до н.е.

37. Грузило ромбоподібної форми з просвердленим отвором - O-2005, Некр. ЮЗ (ус)/108. Щільний вапняк (рис. 2, 24).

54 Молев Е.А. 0 рыболовстве в Китее... С. 132, фото 23. 
Розміри: 3,4×6,7×10,5 см, діаметр отвору 1,3 см. Вага 224 грама.

Знайдене на садибі Широка балка 7 у приміщенні 2 (кухня) напівземлянки I, яка датується рубежем V-IV - першою третиною IV ст. до н.е.

\section{IV група - грузила свинцеві}

38. Грузило усічено-конічне з отвором - 0-2009, Некр. Ю3/269. Свинець (рис. 2, 25).

Розміри: висота 2,3 см, діаметр верхньої частини 0,8 см, діаметр нижньої 1,5 см, діаметр отвору 0,1-0,2 см (верх /низ). Вага 22 грама.

Знайдене на садибі Широка балка 7 , підйомний матеріал.

39. Грузило кільцеподібне з отвором - 0-2009, Некр. Ю3/67. Свинець.

Розміри: діаметр верхньої частини 2,3 см, діаметр нижньої 2,45 см, діаметр отвору 1,2 см. Вага 12 грамів.

Знайдене на садибі Широка балка 7 на південний захід від приміщення 13 житлового будинку, який датується другою третиною - 30-ми роками IV ст. до н.е.

40. Грузило овальної форми з отвором - 0-2011, Некр. ЮВ.ШБ /199а. Свинець (рис. 3, 5).

Розміри: 1,2×1,7 см, отвір 0,7-0,7 см. Вага 11 грамів.

Знайдене на садибі Широка балка 6, підйомний матеріал.

Аналогія грузилам № 39-40 - грузила з Карантинної бухти у Херсонесі55.

\section{REFERENCES}

Blavatskiy, V.D. (1961). Antichnaia arkheologiia Severnogo Prichernomoria [Ancient archaeology of the Northern Black Sea]. Moskva: Izdatelstvo Akademii nauk SSSR [in Russian].

Butyagin, A.M. (2010). Proizvodstvo i ispolzovanie piramidalnykh keramicheskikh gruzil na antichnom Bospore [Production and use of pyramidal ceramic sinkers in antique Bosporus]. Bosporskie chteniya XI, (pp. 50-55) [in Russian].

Bylkova, V.P. (2007). Nizhnee Podneprovie v antichnuiu epokhu (po materialam raskopok poseleniy) [Lower Dnieper in the Ancient Era (based on excavations of settlements)]. Kherson [in Russian].

Biletskyi, O.I. (Comp.). Antychna literature [Ancient literature]. Kyiv: Radianska shkola, 337-349 [in Ukrainian].

Gaidukevich, V.F. (1952). K voprosu o tkatskom remesle v bosporskikh poseleniyakh Bosporskie goroda [On the issue of weaving in the Bospor settlements Bospor cities]. Materialy $i$ issledovaniia po arkheologii SSSR, 25, 395-414 [in Russian].

Khmelevskiy, D.N. (2015.). Svintsovye izdeliya uchastka «T» Berezanskogo antichnogo poseleniya [Lead products of the Section 'T' of the Berezan' ancient settlement]. Arkheologiya i davnia istoriya Ukrainy, 1 (14), 223-228 [in Russian].

Ievlev, M.M. (2004). Rol ikhtiofauny v zhizni antichnogo naseleniya Nizhnego Pobuzhya [The role of ichthyofauna in the life of the ancient population of the Lower Pobuzhya]. Proceedings of the Conference: Borysthenika-2004, (p. 99). Nikolaev [in Russian].

Kryzhitskyi, S.D., Buiskii, S.B., Burakov, A.V. \& Otreshko, V.M. (1989). Selskaya okruga Olvii [Rural district of Olbia]. Kiev: Naukova dumka [in Russian].

Kryzhytskyi, S.D. (1995). Pro vplyv zmin otochuyuchoho seredovyshcha na istorychnyi rozvytok Olviyskoyi derzhavy [On the impact of changes in the environment on the historical development of the Olbia State]. Arkheolohiia, 2, 13-25 [in Ukrainian].

Kryzhitskiy, S.D., $\quad$ Rusyaeva, A.S., $\quad$ Krapivina, V.V., $\quad$ Leipunskaya, N.A., $\quad$ Skrzhinskaya, M.V. \& Anokhin, V.A. (1999). Olviya. Antichnoe gosudarstvo v Severnom Prichernomorie [Olbia. Ancient Greek State in the Northern Coast of the Black Sea]. Kiev [in Russian].

Kulikov, A.V. (1998). Materialy k izucheniyu drevnikh morskikh promyslov [Materials for the study of ancient marine industries]. Drevnosti Bospora, 1, 186-201 [in Russian].

Kulikov, A.V. (2005). Arkheologicheskie svidetelstva rybolovstva na antichnom gorodishe Akra [Archaeological evidence of fishing in the ancient city of Acre]. Bosporskie issledovaniya, 9, 251-270 [in Russian].

Lyashenko, N.F. (2007). O rybakakh i rybnom promysle v antichnuyu epokhu [About fishermen and

55 Рейда Р.Н., Бейлина С.А. Кольцевые свинцовые грузила из Карантинной бухты... Рис. 1. 
fishing in ancient times]. Rybne gospodarstvo Ukrainy, 3-4, 73-78 [in Russian].

Lyashenko, N.F. \& Lyashenko, Yu.N. (2005). O pervykh rybolovakh Vostochnogo Kryma [About the first fishermen of the Eastern Crimea]. Rybnoe hoziaistvo Ukrainy, 1, 48-49 [in Russian].

Molev, E.A. (2011). O rybolovstve v Kitee [About fishing in Kitee]. Bosporskie issledovaniya, XXV, 123-142 [in Russian].

Odrin, 0. (2020). Pryrodni resursy ta torgivelno-ekonomichnyi potentsial antychnykh derzhav Pivnichnogo Prychornomoria: Nyzhne Podnistrovya ta Nyzhne Pobuzhzhia [Natural resources and trade and economic potential of the ancient states of the Northern Black Sea Coast: Lower Transnistria and Lower Pobuzhye]. Kyiv [in Ukrainian].

Onaiko, N.A. (1956). 0 fanagoriiskikh gruzilakh [About Fanagoria sinkers]. Fanagoriya. Materialy $i$ issledovaniya po arkheologii SSSR, 57, 154-160 [in Russian].

Otreshko, V.M. (1976). Pozdnearkhaicheskie poseleniya Berezanskogo limana [Late archaic settlements of the Berezan estuary]. Otkrytiya molodykh arkheologov Ukrainy, (Vol. I, p.32). Kiev: Naukova dumka [in Russian].

Papanova, V.A. \& Diatroptov, P.D. (2017). Graffiti s prigorodnykh usadeb Olvii [Graffiti from the suburban estates of Olbia]. Pivnichne Prychornomoria za antychnoi doby. Kyiv, pp. 82-93 [in Russian].

Papanova, V.A. \& Lyashko, S.M. (2017). Gospodarski sporudy v sistemi prymiskykh sadib Olvii Pontiiskoi (pidsumky rozkopok 2003-2013 rr.) [Household buildings in the system of Olbio suburban estates (the results of excavations of 2003-2013)]. In Matera, M. \& KarasiewiczSzczypiorski, R. (Eds.). The Crimea and the Northern Black Sea Coast in Archaeological Research 1956-2013. Swiatowit Supplement Series C: Pontika et Caucasica, Vol. I. Warsaw: Institute of Archaeology of the University of Warsaw, (pp. 249-258) [in Ukrainian].

Papanova, V.A. \& Lyashko, S.N. (2007). Otchet. Okhrannye raskopki v yugo-zapadnoi chasti nekropolia Olvii («Usadba», uchastok "Zapadnyi»] [Report. Security excavations in the southwestern part of the Olbia necropolis («Usadba», «Zapadnyi» site)]. The Scientific Archive of Institute Archaeology of NAS Ukrsaine. 2007/1g [in Russian].

Papanova, V.A. \& Lyashko, S.N. (2015). Prigorodnye usadby olviiskoi khory V-IV vv. do n.e. [Suburban estates of the Olbia choir of the $5^{\text {th }}-4^{\text {th }}$ centuries BC]. Stratum plus, 3, 227-236 [in Russian].

Papanova, V.A. \& Lyashko, S.M. (2018). Vyroby iz zaliza klasychnoho chasu z prymiskikh sadyb Olvii [Ironwork of classical time from the suburban estates of Olbia]. Arkheolohiia, 2, $71-79$ [in Ukrainian].

Reida, R.N. \& Beilina, S.A. (2013). Koltsevye svintsovye gruzila iz Karantinnoi bukhty [Ring lead sinkers from Quarantine Bay]. Proceedings of the Conference: Pidvodna tekhnika i tekhnolohiya, pp. 124-127 [in Russian].

Semenov-Zuser, S.A. (1947). Rybnyi rynok v Khersonese [Chersonese Fish Market]. Vestnik drevnei istorii, 2 (20), 239-240 [in Russian].

Shtytelman, F.P. (1958). Poselennia bilia Zakysovoyi Balky [Settlement near Zakysova Balka] Arkheolohichni pamiatky URSR, Vol. II, 131-142 [in Ukrainian].

Solomonik, E.I. (1994). Khersonesskie glinianyie gruzila s nadpisyami [Chersonese clay inkers with inscriptions]. Severo-Zapadnyi Krym v antichnuiu epokhu. Kiev, pp. 138-158 [in Russian].

Treshev, A.I. (1974). Nauchnye osnovy selektivnogo rybolovstva [Scientific Basics of Selective Fisheries]. Moskva: Pishchevaya promyshlennost [in Russian].

Zhuravlov, O.P. \& Iievlev, M.M. (2020). Tvarynnytstvo, myslyvstvo ta pryrodne seredovyshche olviiskoi derzhavy arkhaichnykh chasiv [Stockbreeding, hunting and the natural environment of the Olbia State of Archaic Times]. Kyiv: Vydavnytstvo Oleha Filiuka [in Ukrainian]. 


\section{Valentina Papanova}

(Berdyansk State Pedagogical University, Berdyansk, Ukraine)

e-mail: vpapanova1953@gmail.com

ORCID https://orcid.org/0000-0003-3633-3598

\section{Svitlana Lyashko}

(Biographical Research Institute of the Vernadsky National Library of Ukraine, Kyiv, Ukraine) e-mail: lyashko.svetlana@gmail.com

ORCID https://orcid.org/0000-0003-2250-6718

\section{Fishing gear found in suburban estates of Olbia}

The article is devoted to the analysis and classification of 41 fishing sinkers from the suburban estates of Olbia - Shyroka Balka 6 (Broad Hollow) of the second third of the $V^{\text {th }}$ - the beginning of the III ${ }^{\mathrm{d}}$ century BC and Shyroka Balka 7 (Broad Hollow) of the late $\mathrm{V}^{\text {th }}-30$-ies of the IVth century BC.

For today, there are no statistics and a complex typological classification of these artefacts for all periods of Olbia existence and its agricultural area. It complicates their study, the definition of its functional purpose, the creation of an appropriate typology, as well as does not contribute to improving the classification of fishing gear, the study of processes, methods, features of fishing in specific regions. In addition, the functional purpose of some types of sinkers is still controversial.

Sinkers found on the estates differ from each other in material and means of manufacture. An additional indicator of sinkers is their shape. An essential feature for determining the functional purpose is weight. According to the criteria mentioned, they were divided into four conditional groups. The first one is ceramic sinkers, made of auxiliary products (walls of amphorae, from lids of vessels, pallets of black-lacquered kiliks). The second one is ceramic sinkers, made in molds and molded (rounded, disc-shaped, pyramidal, balls with a hole). The third one is stone sinkers (disc-shaped, annular, quadrangular). Fourth one is lead sinkers (cone-shaped, circular). We would like to mention a rare ceramic sinker made of graffiti in the form of tuna.

The answer to the question of the practical use of sinkers from estates should be found in the interdisciplinary space and analysis of the relationship of specific fishing gear with the characteristics of the relevant water area and fish species, which have developed over millennia.

Keywords: Olbia, estates, fishing, sinkers, classification, interdisciplinary space 